\title{
Effects of maintaining solstice light and temperature on reproductive activity, coat growth, plasma prolactin and melatonin in goats
}

\author{
F. E. Gebbie ${ }^{1 *}$, I. A. Forsyth ${ }^{1+}$ and J. Arendt ${ }^{2}$ \\ ${ }^{1}$ The Babraham Institute, Babraham, Cambridge CB2 4AT, UK; and ${ }^{2}$ School of Biological Sciences, \\ University of Surrey, Guildford GU2 5XH, UK
}

\begin{abstract}
Interactive effects of light and temperature on aspects of seasonality were studied in female British Saanen dairy goats. Four groups of adult non-pregnant non-lactating goats $(n=5)$ were housed under the following conditions: controls (July-June): natural photoperiod and temperature; group 1 (July-December): long days (16 h light: 8 h dark) and natural temperature; group 2 (July-December): long days and average summer temperature $\left(17.6^{\circ} \mathrm{C}\right)$; group 3 (December-June): short days ( $8 \mathrm{~h}$ light: $16 \mathrm{~h}$ dark) and winter temperature $\left(8.4^{\circ} \mathrm{C}\right)$. Plasma prolactin and progesterone were measured once a week, circadian changes in prolactin and melatonin were determined in December and May, and coat development was assessed. Seasonal variation in prolactin was influenced by manipulation of both daylength and temperature. In group 1, prolactin concentrations decreased as the environmental temperature decreased, despite maintenance of long days. When light and temperature were maintained under summer (group 2) and winter (group 3) conditions, prolactin remained relatively constant, although at different high and low set points, respectively, but with indications of a seasonal rhythm. An asymptotic relationship between prolactin and temperature was maintained under all daylengths. The circadian pattern of melatonin was related to daylength and was not influenced significantly by temperature. Onset of oestrus was unaltered. In group 3 (maintained winter solstice light and temperature), anoestrus was delayed $(P<0.05)$ from a median control date of 17 March to a median date of 28 April. Winter coat development was delayed in group 1; group 2 showed premature moulting of the winter coat; and in group 3, development of the summer coat was delayed. The results imply that temperature modifies the influence of daylength on prolactin secretion and hair follicle growth by mechanisms that do not involve melatonin.
\end{abstract}

\section{Introduction}

In temperate regions, goats, like sheep and deer, show well marked seasonal cycles of reproductive activity, coat growth and prolactin secretion (Simpson et al., 1984; Lincoln, 1990). An endogenous circannual rhythm appears to be responsible in part, but environmental cues are needed to maintain a synchronized cycle period of $\mathbf{1 2}$ months. Photoperiod is the dominant environmental factor in timing seasonal change through its influence on melatonin. By imposing alternating periods of short and long days, annual cycles can be compressed in pineal-intact sheep and deer (Rougeot, 1961; Simpson et al., 1984) without controlling other environmental variables such as temperature. Similarly, melatonin alone can be used to modify seasonal breeding patterns in goats (Deveson et al., 1992) and other ruminants.

*Present address: Scottish Agricultural College, Ferguson Building, Craibstone Estate, Bucksburn, Aberdeen AB21 9YA, UK

tCorrespondence.

Received 1 May 1998.
However, the entrainment of seasonally influenced physiological events may be fine-tuned by other factors. In large mammals, evidence on the role of environmental temperature in the control of reproduction is limited and inconsistent. Dutt and Bush (1955) reported that, in the ewe, the onset of ovarian activity could be advanced by lowering the air temperature. In contrast, Wodzicka-Tomaszewska et al. (1967) found no effect of a reversed thermal season on reproduction in ewes. Jackson et al. (1989) used a design in which ewes were switched between inductive short days $(8 \mathrm{~h}$ light: $16 \mathrm{~h}$ dark) and inhibitory long days ( $16 \mathrm{~h}$ light: $8 \mathrm{~h}$ dark) at different times of the year. A highly significant negative correlation was found between ambient temperature and interval to cessation of the oestrous cycle in response to $16 \mathrm{~h}$ light: $8 \mathrm{~h}$ dark. There was no correlation between ambient temperature and onset of the oestrous cycle in response to 8 h light: 16 h dark.

There is more consistent evidence that temperature modulates a dominant photoperiodic effect on prolactin (Prandi et al., 1988). In heifers, basal prolactin concentrations 
respond within 5-6h and decrease in response to low temperature and increase in response to high temperature at constant photoperiod (Wettemann et al., 1982). Recent studies indicate a direct role for prolactin in the control of coat growth (Lincoln, 1990; Choy et al., 1997), but prolactin does not appear to be involved directly in seasonal breeding (Lincoln, 1990; Curlewis, 1992).

The aim of the present study was to distinguish the effects of light and temperature by exposing goats at mid-summer or mid-winter to maintained solstice conditions of daylength with or without control of temperature. An overriding effect of temperature on plasma concentrations of prolactin but not of melatonin was expected. If differences in plasma prolactin concentrations between groups could be sustained by temperature manipulation, it was anticipated that there would be effects on the autumn moult or spring regrowth of hair, but that reproductive activity would not be affected. Brief reports of some of this work have been published (Gebbie et al., 1993, 1994).

\section{Materials and Methods}

\section{Animals}

Non-pregnant non-lactating British Saanen goats aged 2-3 years were used. The animals had not been subjected to photoperiodic or other experimental manipulation before this study. The goats were assigned to four groups (five goats per group) by body weight, age and parity, and were allocated at random to treatments. The goats were fed hay ad libitum and given a supplement concentrate $(0.5 \mathrm{~kg}$ per goat per day, $14 \%$ protein, Superstock Nuts; Dalgety Agriculture Ltd, Almondsbury, Bristol) that was divided into two feeds and fed at fixed times (08:00 $\mathrm{h}$ and 14:00 $\mathrm{h}$ ) each day. Water and vitamin and mineral blocks were always available. All goats were penned indoors $\left(11.4 \mathrm{~m}^{2}\right.$ or $\left.14 \mathrm{~m}^{2}\right)$ at the Babraham Institute (latitude $52^{\circ} 7^{\prime} \mathrm{N}$ ) in treatment groups under either natural environmental conditions or controlled conditions of light and temperature (see below). Goats were weighed once a week and body weight was unaffected by treatment.

\section{Control of temperature and photoperiod}

Temperature control was provided by a heating and cooling unit, controlled manually by adjustment of a thermostat to maintain a constant room temperature. The minimum and maximum temperatures experienced by all goats were recorded once a day. Photoperiod control was provided in light-proof rooms by two $300 \mathrm{~W}$ tungstenhalogen lamps (Power Lite, British Lighting Institute, Reading) linked to programmable timers. The illumination at goat eye level (mean $\pm \mathrm{SEM}, n=10$ ) was $368 \pm 29$ lux.

\section{Experimental design}

Goats were maintained under the following conditions: controls: July 1991-July 1992, natural photoperiod and temperature; group 1: July 1991-December 1991, long days (16 h light: $8 \mathrm{~h}$ dark, lights on at $06: 00 \mathrm{~h}$ ) and natural temperature; group 2: July 1991-December 1991, long days and average summer temperature $\left(17^{\circ} \mathrm{C}\right)$; group 3: December 1991-June 1992, short days ( $8 \mathrm{~h}$ light: $16 \mathrm{~h}$ dark, lights on at $07: 00 \mathrm{~h})$ and average winter temperature $\left(5.5^{\circ} \mathrm{C}\right)$. Goats in groups 1, 2 and 3 were maintained under natural light and temperature until transferred into experimental rooms. Daylength at the start of the experiment in July was $16 \mathrm{~h}$ $29 \mathrm{~min}$ and in December was $7 \mathrm{~h} 47 \mathrm{~min}$, so no abrupt changes in daylength were experienced. A group maintained from December to June on $8 \mathrm{~h}$ light: $16 \mathrm{~h}$ dark and natural temperature was initiated, but had to be excluded because of failure of daylength control.

\section{Sampling}

Blood samples $(5 \mathrm{ml})$ were taken by jugular venepuncture and plasma was stored at $-20^{\circ} \mathrm{C}$ using heparin as anticoagulant. Prolactin and progesterone were analysed in blood samples taken once a week at 09:00 h, starting in the first week of treatment (week 1 for control, group 1 and group 2 goats; week 25 for group 3 goats). At the start of each experimental period, there was no significant difference in prolactin concentrations $(P>0.05)$ among groups. Over a $24 \mathrm{~h}$ period in December 1991 and May 1992, blood samples were taken once every $2 \mathrm{~h}$ from 10:00 $\mathrm{h}$ to $16: 00 \mathrm{~h}$ and once an hour from $16: 00 \mathrm{~h}$ to $10: 00 \mathrm{~h}$ for assay of prolactin and melatonin. A dim red light ( $<1$ lux) was used during the hours of darkness.

Coat growth was measured by clipping a $10 \mathrm{~cm} \times 10 \mathrm{~cm}$ patch over the rib cage at 8 week intervals, alternating the side of the goat sampled. The clippings were weighed. Snip biopsies of skin were taken every 4 weeks under local anaesthesia ( $0.5 \mathrm{ml}$ intradermally, lignocaine with adrenaline; Norbrook Laboratories (GB) Ltd, London), fixed in Bouin's fluid and embedded in paraffin wax. One in five serial transverse sections $(6 \mathrm{~mm})$ was mounted and stained with haematoxylin and eosin. The sections were examined under a dissecting microscope $(\times 50)$ to identify trios of primary follicles sectioned at the level of the sebaceous glands. The number of secondary follicles was counted using $\times 100$ magnification for three primary trios per goat on each sampling date and the secondary:primary follicle ratio (S:P) was calculated. A limited number of slides (5/175) could not be assessed because they were sectioned in the wrong plane.

\section{Immunoassays}

Melatonin was measured using a direct radioimmunoassay (English et al., 1986) validated for goat plasma by Deveson et al. (1990). The primary antibody was kindly provided by Stockgrand Ltd (University of Surrey, Guildford), melatonin for standards was from Sigma (Poole), and 2-[125I]iodomelatonin was from Amersham International plc (Little Chalfont). The sensitivity of the assay was $0.5 \mathrm{pg} \mathrm{ml}^{-1}$. The intra- and interassay coefficients of variation (CV) for low, medium and high quality controls were $8.2,2.5$ and $6.7 \%$ 
$(n=4)$ and $21.7,16.2$ and $18.7(n=16)$, respectively. Prolactin and progesterone were measured as described by Forsyth $e$ t al. (1997). The sensitivity of the assay for prolactin was $0.3 \mathrm{ng}$ NIH-P-S-18 $\mathrm{ml}^{-1}$ and intra- and interassay $\mathrm{CV}$ averaged 7.9 and $18.0 \%$, respectively. The sensitivity of the assay for progesterone was $0.2 \mathrm{ng} \mathrm{ml}^{-1}$ and intra- and interassay $\mathrm{CV}$ averaged 6.8 and $23.1 \%$, respectively. Progesterone concentrations $>2 \mathrm{ng} \mathrm{ml}^{-1}$ in two successive samples were considered to indicate ovarian activity.

\section{Statistical analysis}

Analysis was carried out using the statistical packages Multistat, Genstat 5 or SuperANOVA. Changes in prolactin concentrations in the samples taken once a week, the weight of fibre samples and the S:P ratios were subjected to two-way ANOVA with respect to treatment and time in a repeated measures analysis. Each treatment group was compared with controls sampled over the same time period (groups 1 and 2 with July-December controls; group 3 with DecemberJune controls). From the $24 \mathrm{~h}$ profiles, the timing of the nocturnal increase and decrease in prolactin and melatonin was assessed by comparison with the respective group daylight baseline using Student's $t$ test. For onset and cessation of ovarian activity, a fixed time point (week 1,9 July 1991) was defined. The number of weeks for plasma progesterone to increase above (onset) or decrease below (cessation) $2 \mathrm{ng} \mathrm{ml}^{-1}$ in two successive samples was calculated for each goat. Difference from controls was tested using the non-parametric Mann-Whitney U test.

\section{Results}

\section{Control of temperature}

Control goats experienced maximum summer temperatures of $22^{\circ} \mathrm{C}$ (week $1,9 \mathrm{July}$ ) and $21^{\circ} \mathrm{C}$ (week 48 , 2 June). The minimum winter temperature was $5^{\circ} \mathrm{C}$ (week 29,21 January, Fig. 1a). The summer temperature of $17^{\circ} \mathrm{C}$ selected for group 2 was well maintained (Fig. 1c, weekly mean $17.6^{\circ} \mathrm{C}$, range $16.7-19.1^{\circ} \mathrm{C}$ ). The cooling system was unable to maintain the selected winter temperature of $5.5^{\circ} \mathrm{C}$, and group 3 experienced some temperature fluctuation (Fig. 1d, mean $8.4^{\circ} \mathrm{C}$, range $5.1-12.3^{\circ} \mathrm{C}$ ).

\section{Circannual prolactin secretion}

Control goats showed the expected seasonal changes in plasma prolactin, and concentrations were highest in summer and lowest in winter (week 3, 23 July, $228 \pm 78 \mathrm{ng}$ $\mathrm{ml}^{-1} ;$ mean $\pm \mathrm{SEM}, n=5$; week 24,17 December, $0.9 \pm 0.4 \mathrm{ng}$ $\mathrm{ml}^{-1}$; Fig. 1a). An exponential curve (Fig. 2a) related prolactin concentration to temperature in control goats. In all comparisons of control and treatment groups, there was a significant time and group interaction for comparisons of prolactin concentrations (repeated measures ANOVA: controls versus group 1 or group $2, P<0.001$; controls versus group 3, $P<0.01$ ). Despite the maintained long-day photoperiod of $16 \mathrm{~h}$ light: $8 \mathrm{~h}$ dark, prolactin concentrations in group 1 decreased from September to October, but remained higher than in control goats (Fig. 1b) from week $8(P<0.01)$. The exponential curves relating prolactin concentration to temperature (Fig. 2a) were also different $(P<0.05)$ in control and group 1 goats. Group 2 animals $(16 \mathrm{~h}$ light: $8 \mathrm{~h}$ dark and $17.7^{\circ} \mathrm{C}$ ) showed relatively stable prolactin concentrations (Fig. 1c, mean of weekly averages $47.7 \pm$ $18.7 \mathrm{ng} \mathrm{ml}^{-1}$; mean $\left.\pm \mathrm{SD}, n=24\right)$ that were lower $(P<0.005)$ than controls between July and September and higher $(P<0.001)$ between October and December. Despite relatively poor control of temperature, there was a significant main effect of treatment in group $3(P<0.005)$. The combination of short days ( $8 \mathrm{~h}$ light: $16 \mathrm{~h}$ dark) and low temperature $\left(8.4^{\circ} \mathrm{C}\right)$ inhibited $(P<0.005$, Fig. 1d) the spring increase in prolactin that was observed in control goats from April. Prolactin concentrations for groups 2 and 3 were close to the curve relating prolactin to temperature in control goats (Fig. $2 \mathrm{~b}, \mathrm{c}$ ).

\section{Circadian variation in plasma melatonin and prolactin}

The nocturnal increase in melatonin corresponded to the natural or imposed short- and long-day photoperiods. Plasma melatonin over $24 \mathrm{~h}$ is shown for control goats in December (Fig. 3a) and May (Fig. 3d), for group 1 (Fig. 3b) and group 2 (Fig. 3c) in $16 \mathrm{~h}$ light: $8 \mathrm{~h}$ dark in December, and for group 3 (Fig. 3e) in $8 \mathrm{~h}$ light: $16 \mathrm{~h}$ dark in May. There was no significant effect on melatonin of summer temperature in December (group 2) or winter temperature in May (group 3). Prolactin showed a biphasic nocturnal pattern, and increased at natural or imposed dusk with a smaller peak at dawn (Fig. 3a-e). The $16 \mathrm{~h}$ light: $8 \mathrm{~h}$ dark photoperiod resulted in an increase in basal prolactin concentration in groups 1 and 2 above that in the controls $(P<0.001)$.

There was a close relationship between nocturnal increase in melatonin in darkness and the onset of the dusk peak and the decrease in the dawn peak in prolactin (Fig. 3). In control goats sampled in December, both melatonin and prolactin increased between 16:00 h and 17:00 h and decreased between 08:00 $\mathrm{h}$ and 09:00 $\mathrm{h}$. In groups 1 and 2 in 16 h light: $8 \mathrm{~h}$ dark, the dusk increase in melatonin and prolactin began between 22:00 $\mathrm{h}$ and 23:00 $\mathrm{h}$ and the dawn decrease was between $07: 00 \mathrm{~h}$ and 08:00 h. At the end of May, both melatonin and prolactin increased in control goats at 21:00 h and decreased at 06:00 h. In group 3 goats in $8 \mathrm{~h}$ light: $16 \mathrm{~h}$ dark, increases and decreases were at 16:00 h and 07:00 h, respectively.

\section{Ovarian activity}

The cumulative onset of recurring cycles of ovarian activity, as determined from plasma progesterone concentrations taken once a week, is shown (Fig. 4a). In control goats $(n=5)$, the median onset date was 19 November. Onset of ovarian activity was not affected $(P>0.05$, Mann-Whitney $U$ test) by maintaining either 


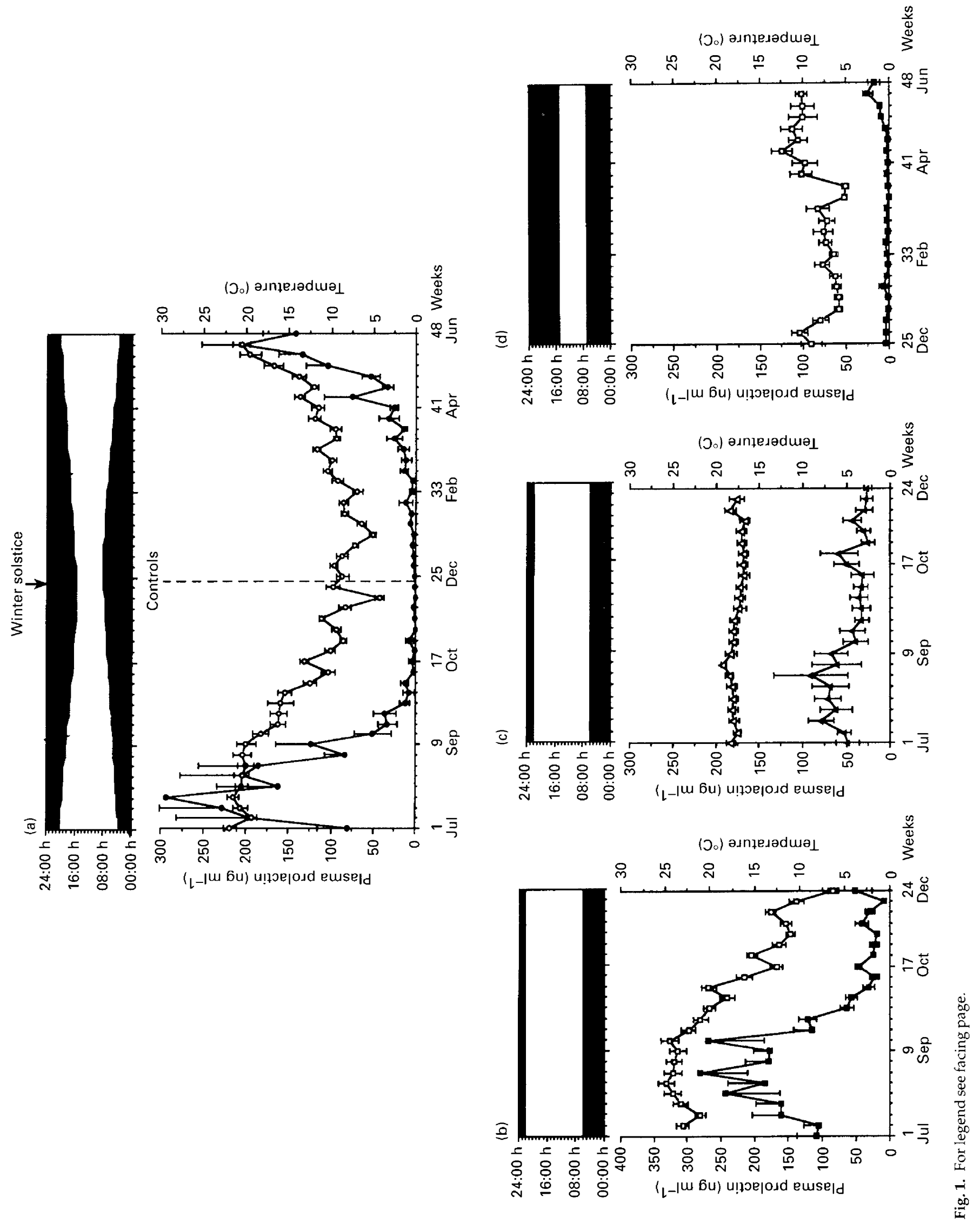



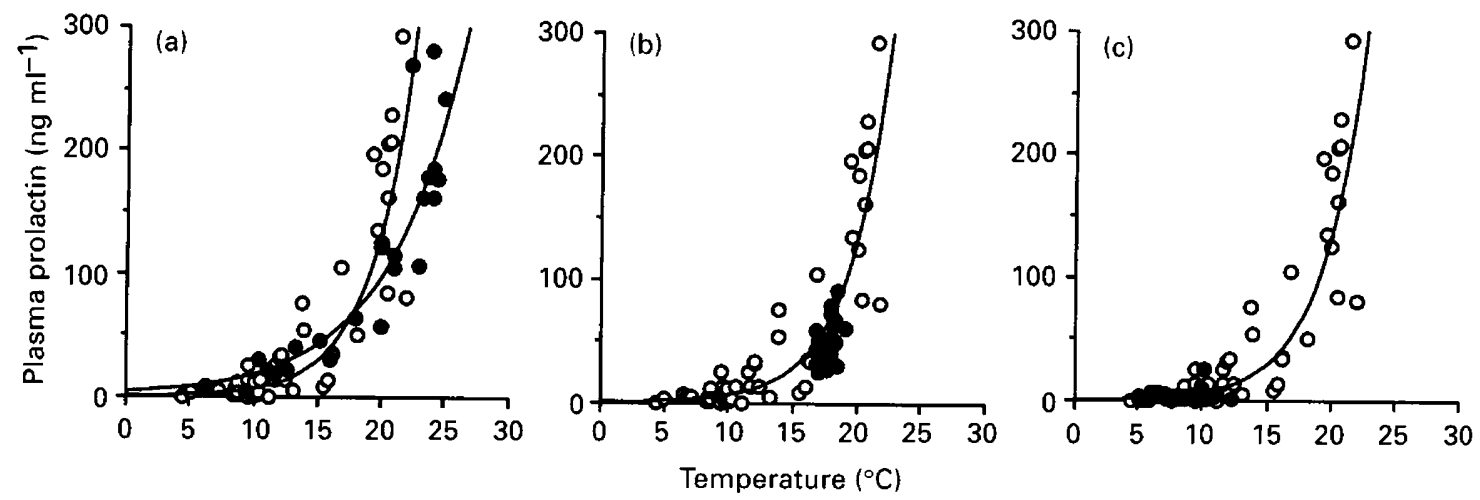

Fig. 2. Fitted curves relating mean $(n=5)$ plasma prolactin concentration measured once a week $\left(\mathrm{ng} \mathrm{ml}^{-1}\right) \mathrm{with}^{\mathrm{t}}$ environmental temperature $\left({ }^{\circ} \mathrm{C}\right)$ in (a) control goats $(\mathrm{O}$, natural photoperiod and temperature, $r=0.843, \mathrm{df} 46, P<0.001)$ and group 1 goats $(\bullet, 16 \mathrm{~h}$ light: $8 \mathrm{~h}$ dark, natural temperature, $r=0.958, \mathrm{df} 22, P<0.001)$; (b) control goats $(O)$ and group 2 goats $\left(\bullet, 16 \mathrm{~h}\right.$ light: $8 \mathrm{~h}$ dark, $\left.17.6^{\circ} \mathrm{C}\right)$; and $(\mathrm{c})$ control goats $(\mathrm{O})$ and group 3 goats $\left(-8 \mathrm{~h}\right.$ light: $16 \mathrm{~h}$ dark, $\left.8.4^{\circ} \mathrm{C}\right)$.

summer photoperiod (group 1, $n=5$, median 22 October) or summer photoperiod and temperature (group 2, $n=4$, one goat with suspected cystic ovaries omitted; median 5 November). Maintaining winter photoperiod and temperature delayed $(P<0.05)$ the end of the breeding season (Fig. 4b; controls, $n=5$; median cessation date 17 March; group 3, $n=5$; median 28 April).

\section{Development of the coat}

The weight of coat samples varied with season (Fig. 5a; $P<0.001$, ANOVA) and there was an interaction $(P<0.01)$ between month and treatment in the period July-December. Group 2 ( $16 \mathrm{~h}$ light: $8 \mathrm{~h}$ dark and $\left.17.7^{\circ} \mathrm{C}\right)$ had smaller coat weights in December compared with control goats (17 December: control, $n=5,3.5 \pm 0.2 \mathrm{~g}$, mean $\pm \mathrm{SEM}$; group $2, n=5$, $2.8 \pm 0.1 \mathrm{~g}, P<0.01$, Student's $t$ test). Effects of both season $(P<0.01)$ and treatment $(P<0.001)$ were evident from the study of S:P ratios (ANOVA). In control goats, the S:P ratio reached a maximum in December, as did coat weight, and decreased rapidly from February to April (Fig. 5a). Goats in $16 \mathrm{~h}$ light: $8 \mathrm{~h}$ dark and natural temperature (group 1) generally had a low S:P ratio compared with controls (Fig. $5 b$ ), and there were significant differences in October and December $(P<0.05)$. An S:P ratio normally seen in the summer was observed in group 2 goats $(16 \mathrm{~h}$ light: $8 \mathrm{~h}$ dark and $17.7^{\circ} \mathrm{C}$ ) in November and December (Fig. $5 \mathrm{c}, P<0.001$ ). In $8 \mathrm{~h}$ light: $16 \mathrm{~h}$ dark and $8.4^{\circ} \mathrm{C}$ (group 3), attainment of a summer S:P ratio was delayed from April until June (Fig. 5d).

\section{Discussion}

The major determinant of seasonal changes in plasma prolactin concentrations is daylength, mediated by melatonin signals from the pineal acting directly at the pituitary, as shown in hypothalamo-pituitary disconnected sheep (Lincoln and Clarke, 1994). Nevertheless, a number of studies have demonstrated rapid (within hours) effects of temperature on basal and stimulated prolactin secretion (Tucker and Wettemann, 1976; Wettemann et al., 1982; Prandi et al., 1988). Although in the present study daylength was maintained in group 1 at $16 \mathrm{~h}$ light: $8 \mathrm{~h}$ dark, prolactin decreased with the seasonal decrease in temperature, but remained above winter control values. In group 2 (summer light and average summer temperature) and group 3 (winter light and winter temperature), the annual variation in prolactin secretion was inhibited and concentrations remained relatively constant, although at different set points (higher in group 2 than group 3). The relationships between prolactin concentration and temperature are consistent with observations in heifers (Peters and Tucker, 1978) that the positive influence of long days on prolactin is limited by low ambient temperatures (group 2). In the present study, this effect is also evident for group 1 below $17^{\circ} \mathrm{C}$ (Fig. 2a). Above $17^{\circ} \mathrm{C}$, the combined effects of decreasing temperature and daylength suppressed prolactin earlier in control goats (significantly lower prolactin concentrations from week 8 , $P<0.01)$. There was a tendency for prolactin concentrations to decrease (group 2) or increase (group 3) towards the end of the 6 month treatment period, indicating an underlying endogenous circannual rhythm. Jackson and Janson (1991) obtained evidence of a low amplitude 354 day periodicity in prolactin secretion in ewes maintained at $20^{\circ} \mathrm{C}$ under $12 \mathrm{~h}$ light: $12 \mathrm{~h}$ dark for 3 years. Over 4 years, superior cervical ganglionectomized Soay rams housed indoors showed a 52 week periodicity in prolactin (Lincoln et al., 1989).

The circadian pattern of melatonin concentrations in goats in December and May corresponded to the photoperiod and was not significantly affected by temperature. Although temperature may affect melatonin in poikilothermic

Fig. 1. Daylength (upper panel), environmental temperature (open symbols) and plasma prolactin concentrations (ng $\mathrm{ml}^{-1}$, solid symbols) taken once a week in (a) control goats (natural photoperiod and temperature, July-June); (b) group 1 goats (16 h light: $8 \mathrm{~h}$ dark, ambient temperature, July-December); (c) group 2 goats (16 h light: $8 \mathrm{~h}$ dark, $17.6^{\circ} \mathrm{C}$, July-December); (d) group 3 goats, $\left(8 \mathrm{~h} \mathrm{light:} 16 \mathrm{~h}\right.$ dark, $8.4^{\circ} \mathrm{C}$, December-June). Values are mean \pm SEM of temperature measurements taken once a day and prolactin values in five goats per group. 

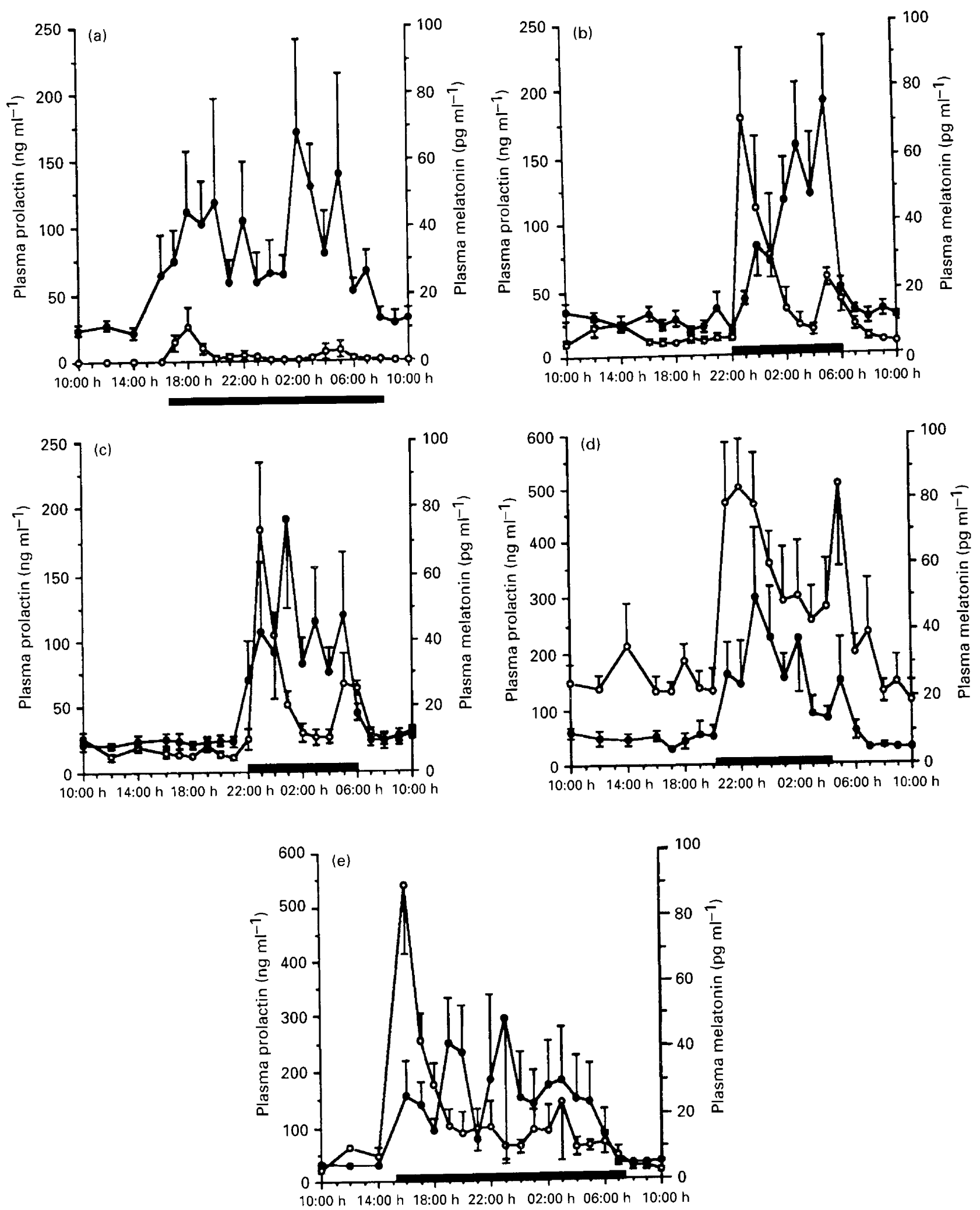

Fig. 3. Concentrations (mean $\pm \mathrm{SEM}$ ) of melatonin $\left(\mathrm{pg} \mathrm{m}^{-1}, \mathbf{0}\right)$ and prolactin $\left(\mathrm{ng} \mathrm{ml}^{-1}, \mathrm{O}\right)$ in plasma samples taken every $2 \mathrm{~h}$ from 10:00 $\mathrm{h}$ to $16: 00 \mathrm{~h}$ and every hour from 16:00 $\mathrm{h}$ to 10:00 h over one $24 \mathrm{~h}$ period in (a) control goats $(n=5)$ in December; (b) group 1 goats (16 h light: $8 \mathrm{~h}$ dark, natural temperature, $n=5)$ in December; (c) group 2 goats $\left(16 \mathrm{~h}\right.$ light: $8 \mathrm{~h}$ dark, $\left.17.6^{\circ} \mathrm{C}, n=5\right)$ in December; (d) control goats $(n=5)$ in May; and (e) group 2 goats $\left(8 \mathrm{~h}\right.$ light: $16 \mathrm{~h}$ dark, $\left.8.4^{\circ} \mathrm{C}, n=5\right)$ in May. Horizontal black bars show the hours of darkness. 
(a)

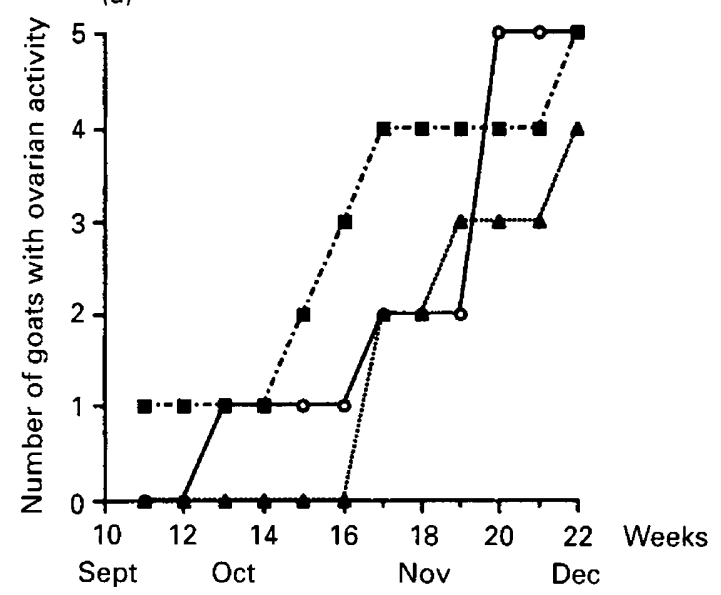

(b)

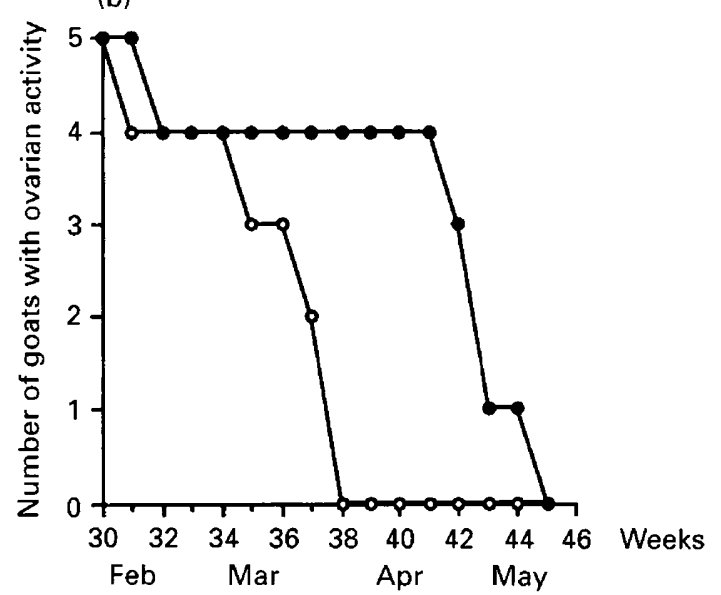

Fig. 4. Cumulative (a) onset and (b) cessation in ovarian activity in goats, as determined from plasma progesterone concentrations measured once a week. Median onset: control goats $(0), 19$ November; group 1 goats $(\boldsymbol{\square}), 22$ October; group 2 goats $(\boldsymbol{A}), 5$ November. Median cessation: control goats $(\bigcirc), 17$ March; group 3 goats (-), 28 April.

vertebrates (Vivien-Roels and Pevet, 1983; Underwood, 1985), there appears to be no effect in goats.

In ruminants, prolactin shows a daily rhythm of secretion and increased nocturnal production. Prolactin profiles often show a dusk and a dawn peak in sheep (Ravault and Ortavant, 1977; Lincoln et al., 1978; Symons et al., 1983) and goats (Mori et al., 1985). In the present study, the pattern of a large dusk and smaller dawn peak was sustained against wide variations in basal prolactin concentrations. The onset of the dusk peak and cessation of the dawn peak corresponded to the nocturnal pattern of melatonin secretion in control goats and in all treatment groups, but provide no information on whether the association is causal. The mechanisms that generate and control the timing of the daily prolactin rhythm are not fully elucidated, but appear to be hypothalamic and not pineal in origin (Lincoln and Clarke, 1994; Houghton et al., 1995). The presence of dusk and dawn peaks may be related to the evening and morning oscillators postulated to control the duration of melatonin secretion and other aspects of circadian rhythmicity (Illnerová and Vanecek, 1988).

Studies in sheep indicate that the onset of reproductive activity in autumn is initiated by the lengthening days of spring entraining an endogenous seasonal rhythm (Malpaux et al., 1989). Anoestrus may also be determined by previous photoperiodic history, since the breeding season is sustained (onset of anoestrus determined) by the duration of decreasing photoperiod before the winter solstice (Malpaux and Karsch, 1990). However, long days may be sufficient to set the whole seasonal cycle (Woodfill et al., 1991). In the present study, all the goats perceived the natural increase in daylength from spring to summer in 1991, and thus would be expected to be synchronous with controls in oestrous onset, as was observed in group 1 (16 h light: $8 \mathrm{~h}$ dark and natural temperature) and group 2 (16 h light: $8 \mathrm{~h}$ dark and maintained average summer temperature). In group 3 ( $8 \mathrm{~h}$ light: $16 \mathrm{~h}$ dark and winter temperature), the synchronizing effect of long days in spring 1991 was reinforced by the natural decrease in photoperiod before entering the experiment in December 1991. Nevertheless, anoestrus was delayed. On 24 March, all control goats were in anoestrus compared with only one of five goats in group 3 . The results of Jackson et al. (1989) indicate that temperature can provide a fine-tuning mechanism at the end of the breeding season in ewes, but further results are needed to determine the relative influences of temperature and photoperiod on cessation of ovarian activity in goats.

Photoperiod is a dominant influence in determining seasonal pelage change and there is considerable evidence that prolactin is involved as a mediator in goats (Dicks et al., 1994), as in other mammals (Badhura and Goldman, 1992). Hair growth shows an endogenous rhythm with a periodicity that is shorter than 1 year in goats maintained in constant light (McDonald et al., 1987) and in pinealectomized sheep (Allain et al., 1994). Prolactin may be involved in synchronizing an endogenous cycle, but there are also indications that it may act directly. The anagen secondary hair follicles of Angora goats are stimulated to grow by prolactin in vitro (Ibraheem et al., 1993) and prolactin binding sites have been detected by autoradiography (Choy et al., 1995) and immunocytochemistry (Choy et al., 1997) in the dermal papillae of hair follicles in sheep.

In goats, primary follicles produce an outer coat of medullated kemp or guard hairs, although the main insulating layer is the undercoat of finer largely nonmedullated fibres (cashmere) produced by secondary follicles (Ryder, 1966). From about the autumn equinox, the primary and secondary follicles pass into an inactive telogen phase and remain dormant until spring, and the guard hairs of the outer coat and the undercoat are retained to provide the thick winter coat. Temporally associated with the spring increase in prolactin concentrations, hair follicles are reactivated (anagen) leading to moulting of the winter coat. Regrowth in secondary follicles in autumn coincides with decreasing prolactin concentrations and re-establishes the fine undercoat. The follicle population is determined at birth, but during the growth cycle the follicles change in length. In skin sections parallel to the skin surface at the mid-level of the sebaceous glands, the ratio of secondary to a trio of 

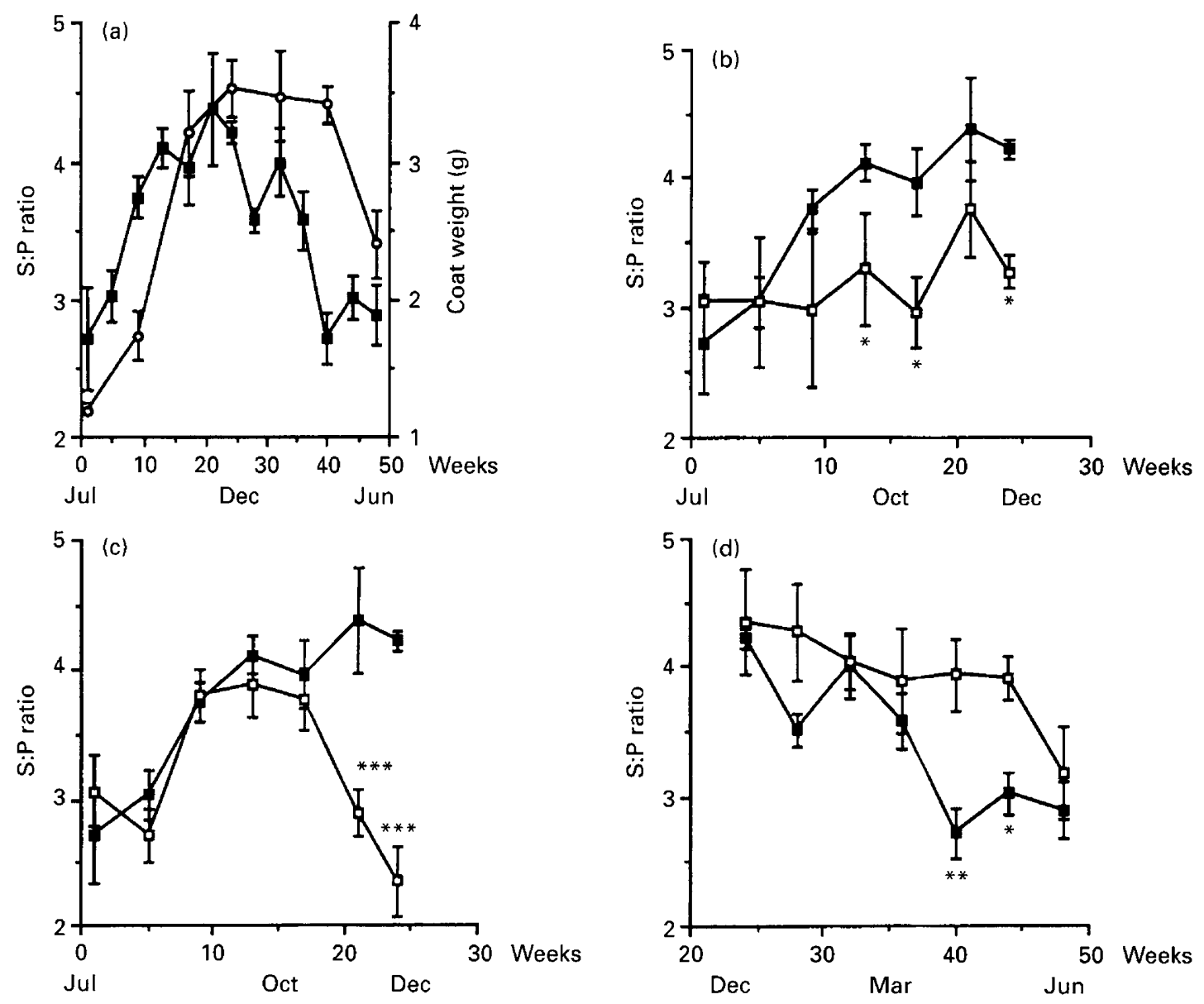

Fig. 5. Changes in coat development in goats exposed to different photoperiods and temperatures. (a) Weight of fibre from a $10 \mathrm{~cm} \times 10 \mathrm{~cm}$ side patch $(O)$ and secondary:primary follicle ratio (S:P) (ם) at intervals of 8 weeks during 1 year, July-June, in control goats. (b) S:P ratio in group 1 goats $(\square, 16 \mathrm{~h}$ light: $8 \mathrm{~h}$ dark, natural temperature, July-December). (c) S:P ratio in group 2 goats $\left(\square, 16 \mathrm{~h}\right.$ light: $8 \mathrm{~h}$ dark, $17.6^{\circ} \mathrm{C}$, July-December). (d) S:P ratio in group 3 goats $\left(\square, 8 \mathrm{~h}\right.$ light: $16 \mathrm{~h}$ dark, $8.4^{\circ} \mathrm{C}$, December-June). The S:P ratio for control goats over the same time period ( $(\mathbf{\square})$ is shown for comparison in (b), (c) and (d). Values are mean \pm SEM for five goats per group. ${ }^{*} P<0.05$; ${ }^{* *} P<0.01$; ${ }^{* * *} P<0.001$.

primary follicles gives an indication of the development of the cashmere undercoat. At this level, the S:P ratio is typically highest in autumn and winter and lowest in mid-summer. In group 1 goats, prolactin concentrations decreased later than in controls and the S:P ratio was generally lower, indicating a delay in autumn cashmere development, although coat weight was not affected. The prolactin concentration in group 2 goats was lower than the summer maximum, but did not decrease during the autumn. These goats had a lower coat weight in December and a smaller S:P ratio in November and December, consistent with follicle reactivation and premature moulting. In group 3 goats, the spring increase in prolactin was markedly reduced and they retained a winter S:P ratio in April and May, consistent with delayed telogen to anagen transition, and similar to the effects of suppressing the spring increase in prolactin with bromocriptine in cashmere goats (Dicks et al., 1994). Temperature may also affect hair growth via its influence on thyroid hormone (Ebling and Hale, 1970), but this was not examined. Shi and Barrell (1991) observed disruption of seasonal pelage change in thyroidectomized red deer.

In summary, in this study in goats, photoperioddependent circadian changes in melatonin were not affected by temperature. Prolactin concentrations were strongly influenced by both daylength and temperature and may mediate effects on coat growth. Limited effects of maintained winter photoperiod and temperature were observed on cessation of oestrous activity.

This work was supported by the Agricultural and Food Research Council and by a CASE Award from the Science and Engineering Research Council to F. E. Gebbie. Staff of The Babraham Institute gave valuable help with the care and sampling of goats and maintenance of the light and temperature control facility. A. Fraser assisted with the skin histology. The authors thank J. Dauncey and C. L. Gilbert for helpful discussions on experimental design and D. Brown for advice on statistical analysis. The Farm Energy Centre, National Agricultural Centre, Stoneleigh, provided the lighting 
equipment. The authors are grateful for gifts of reagents to J. Foulkes for antibody to progesterone, Stockgrand, Guildford, Surrey, for antibody to melatonin, and the National Hormone and Pituitary Program, Baltimore, MD, USA, for ovine prolactin.

\section{References}

Allain D, Thébault RG, Rougeot J and Martinet L (1994) Biology of fibre growth in mammals producing fine fibre and fur in relation to control by daylength: relationship with other seasonal functions European Fine Fibre Network (occasional publication) 2 23-40

Badhura LL and Goldman BD (1992) Prolactin-dependent seasonal changes in pelage: role of the pineal gland and dopamine Journal of Experimental Zoology 33 27-33

Choy VJ, Nixon AJ and Pearson AJ (1995) Localisation of receptors for prolactin in ovine skin Journal of Endocrinology 144 143-151

Choy VJ, Nixon AJ and Pearson AJ (1997) Distribution of prolactin receptor immunoactivity in ovine skin and changes during the wool growth cycle Journal of Endocrinology 155 265-275

Curlewis JP (1992) Seasonal prolactin secretion and its role in seasonal reproduction: a review Reproduction, Fertility and Development 4 1-23

Deveson SL, Arendt J and Forsyth IA (1990) Sensitivity of goats to a light pulse during the night as assessed by suppression of melatonin concentrations in the plasma Journal of Pineal Research 8169-177

Deveson SL, Forsyth IA and Arendt J (1992) Induced out-of-season breeding in British Saanen dairy goats: use of artificial photoperiod and/or melatonin administration Animal Reproduction Science 29 1-15

Dicks P, Russel AJF and Lincoln GA (1994) The role of prolactin in the reactivation of hair follicles in relation to moulting in cashmere goats fournal of Endocrinology 143 441-448

Dutt RH and Bush LF (1955) The effect of low environmental temperature on initiation of the breeding season and fertility in sheep Journal of Animal Science 14 885-898

Ebling FJ and Hale PA (1970) The control of the mammalian moult. In Hormones and the Environment pp 215-237 Eds GK Benson and JG Phillips. Cambridge University Press, Cambridge

English J, Poulton AL, Arendt J and Symons AM (1986) A comparison of the efficiency of melatonin treatments in advancing oestrus in ewes Journal of Reproduction and Fertility 77 321-327

Forsyth IA, Gebbie FE and Arendt J (1997) Timing of melatonin treatment: differential effects on oestrus and coat growth in goats Animal Science 65 267-273

Gebbie FE, Forsyth IA and Arendt J (1993) Temperature and photoperiod effects on prolactin and melatonin secretion in the goat journal of Reproduction Abstract Series 1194

Gebbie FE, Forsyth IA and Arendt J (1994) Effects of melatonin, bromocriptine and altered light/temperature patterns on coat growth in dairy goats European Fine Fibre Network (occasional publication) 297-105

Houghton DB, Young IR and McMillen IC (1995) Evidence for hypothalamic control of the diurnal rhythms in prolactin and melatonin in the fetal sheep during late gestation Endocrinology 136 218-223

Ibraheem M, Galbraith H, Scaife JR and Ewen S (1993) Growth of secondary hair follicles of the cashmere goat in vitro and their response to prolactin and melatonin Journal of Anatomy 185 135-142

Illnerová $\mathbf{H}$ and Vanecek J (1988) Entrainment of the rat pineal rhythm in melatonin production by light Reproduction, Nutrition et Dévelopment 28 $515-526$

Jackson GL and Janson HT (1991) Persistence of a circannual rhythm of plasma prolactin concentrations in ewes exposed to a constant equatorial photoperiod Biology of Reproduction 44 469-475

Jackson GL, Jansen HT, Kuehl DE and Shanks RD (1989) Time of the sidereal year affects responsiveness to the phase-resetting effects of photoperiod in the ewe Iournal of Reproduction and Fertility 85 221-227

Lincoln GA (1990) Correlation with changes in horns and pelage, but not reproduction, of seasonal cycles in the secretion of prolactin in rams of wild, feral and domesticated breeds of sheep Journal of Reproduction and Fertility 90285-296

Lincoln GA and Clarke II (1994) Photoperiodically-induced cycles in the secretion of prolactin in hypothalamo-pituitary disconnected rams: evidence for the translation of the melatonin signal in the pituitary gland Journal of Neuroendocrinology $6251-260$

Lincoln GA, McNeilly AS and Cameron CL (1978) The effects of a sudden decrease or increase in daylength on prolactin secretion in the ram Journal of Reproduction and Fertility 52 305-311

Lincoln GA, Libre EA and Merriman GR (1989) Long-term reproduction cycles in rams after pinealectomy or superior cervical ganglionectomy Journal of Reproduction and Fertility 85 687-704

McDonald BJ, Hoey WA and Hopkins PS (1987) Cyclical fleece growth in cashmere goats Australian Iournal of Agricultural Research 38 597-609

Malpaux B and Karsch FJ (1990) A role for short days in sustaining seasonal reproductive activity in the ewe Journal of Reproduction and Fertility 90 $555-562$

Malpaux B, Robinson JE, Wayne NL and Karsch FJ (1989) Regulation of the onset of the breeding season of the ewe: importance of long days and of an endogenous reproductive rhythm Journal of Endocrinology 122 269-278

Mori Y, Maeda K, Sawasaki T and Kano Y (1985) Photoperiodic control of prolactin secretion in the goat Japanese Journal of Animal Reproduction 31 9-15

Peters RR and Tucker HA (1978) Prolactin and growth hormone responses to photoperiod in heifers Endocrinology 103 229-234

Prandi A, Motta M, Chiesa F and Tamanini C (1988) Circannual rhythm of plasma prolactin concentration in the goat Animal Reproduction Science 17 $85-94$

Ravault J-P and Ortavant R (1977) Light control of prolactin secretion in sheep. Evidence for a photoinducible phase during a diurnal rhythm Annales de Biologie Animale, Biochimie, Biophysique 17 459-473

Rougeot J (1961) Actions comparées des variations périodique, annuelles et semestrielles, de la durée quotidienne de l'éclairement sur les cycles des follicules des jarres courts de la toison des bresbis limousines. Relations avec leur cycle de reproduction Annales de Biologie Animales, Biochimie, Biophysigue $1385-402$

Ryder ML (1966) Coat structure and seasonal shedding in goats Animal Production 8 289-302

Shi ZD and Barrell GK (1991) Effects of thyroidectomy on seasonal patterns of live weight, testicular function, antler development and moulting in red deer. In The Biology of Red Deer pp 443-449 Ed. RD Brown. Springer-Verlag, New York

Simpson AM, Suttie JM and Kay RNB (1984) The influence of artificial photoperiod on the growth, appetite and reproductive status of male red deer and sheep Animal Reproduction Science 6 291-299

Symons AM, Arendt J and Laud CA (1983) Melatonin feeding decreases prolactin levels in the ewe Journal of Endocrinology $9941-46$

Tucker HA and Wettemann RP (1976) Effects of ambient temperature and relative humidity on serum prolactin and growth hormone in heifers Proceedings of the Society of Experimental Biology and Medicine 151 623-628

Underwood H (1985) Pineal melatonin rhythms in the lizard Anolis carolinensis: effects of light and temperature cycles Journal of Comparative Physiology 157 A57-A65

Vivien-Roels B and Pevet P (1983) The pineal gland and the synchronisation of reproductive cycles with variations of the environmental climatic conditions, with special reference to temperature Pineal Research Review 191-143

Wettemann RP, Tucker HA, Beck TW and Meyerhoeffer DC (1982) Influence of ambient temperature on prolactin concentrations in serum of Holstein and Brahman $\times$ Hereford heifers Journal of Animal Science 55 391-394

Wodzicka-Tomaszewska M, Hutchinson JCD and Bennett JW (1967) Control of the annual rhythm of breeding in ewes: effect of an equatorial daylength with reversed thermal seasons Journal of Agricultural Science, Cambridge 68 $61-67$

Woodfill CJI, Robinson JE, Malpaux BM and Karsch FJ (1991) Synchronisation of the circannual reproductive rhythm of the ewe by discrete photoperiodic signals Biology of Reproduction 45 110-121 